Serebral Palsili Çocukların Beslenme Durumunun Değerlendirilmesi

Determination of Nutritional Status in Children with Cerebral Palsy

\author{
Melda Kangalgil ${ }^{1}$, Ayşe Özfer Özçelik ${ }^{2}$ \\ ${ }^{1}$ Karadeniz Teknik Üniversitesi Sağl1k Bilimleri Fakültesi, Beslenme ve Diyetetik Bölümü, Trabzon \\ ${ }^{2}$ Ankara Üniversitesi Sağlik Bilimleri Fakültesi, Beslenme ve Diyetetik Bölümü, Ankara
}

\title{
$\ddot{O} Z$
}

GİRİ̧̧ ve AMAÇ: Bu çalışma Serebral Palsili (SP) çocukların beslenme durumunu ve bunu etkileyen etmenleri belirlemek amacıyla planlanmış ve yürütülmüştür.

YÖNTEM ve GEREÇLER: Araştırmanın örneklemini, Ankara ilinde yaşayan gelişigüzel örnekleme ile seçilen Serebral Palsi tanısı almış, 7-17 yaş aralığında ve oral beslenebilen 40 çocuk oluşturmuştur. Araştırma verileri anket formu ile çocukların ebeveynlerinden biri ile yüz yüze görüşülerek toplanmıştır. Çocukların besin tüketim durumunu belirlemek için 24 saati hatırlatma yöntemi ile bir günlük besin tüketimleri öğrenilmiştir.

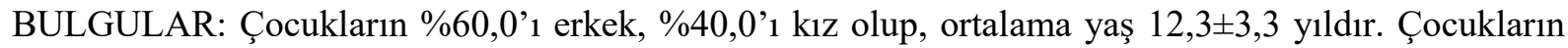
\%30,0'unun aşırı zayıf, \%20,0'sinin zayıf, \%12,5'inin kilolu ve \%2,5'inin obez olduğu bulunurken; sadece \%35,0'inin normal Beden Kütle İndeksi (BKİ)'nde olduğu saptanmıştır. Çocukların \%52,5'inin yemek yeme ile ilgili problemleri olduğu belirlenmiştir. Yemek yerken en çok görülen problemler; yemeği ağzında bekletme $(\% 73,5)$, yemek sırasında yiyecekleri dökme $(\% 58,0)$ ve yemek sırasında öksürme veya tıkanma nöbetidir (\%42,0). Sıklıkla rastlandığı belirtilen sorunlarda en yüksek oranı salya akması almıştır (\%42,5). İki haftadan daha kısa süre içinde karşılaşıldığı belirtilen sorunlarda \%22,5 ile iştahsızlık ve konstipasyon ikinci, yutma ve çiğneme güçlüğü, besinlere ilgisizlik \%20,0 ile üçüncü sıradadır. Serebral Palsili çocukların \%80,0'inin günlük diyetleri ile posay1, \%72,5'inin kalsiyumu, $\% 67,5$ 'inin folatı yetersiz aldıkları belirlenmiştir. Genel olarak enerji alımları yetersiz bulunurken; protein alımlarının yeterli olduğu saptanmıştır.

TARTIŞMA ve SONUÇ: Beslenme sorunlarının belirlenmesi ve soruna özel çözümün belirlenmesi ile beslenme durumunun geliştirilmesi, SP'li çocuklar için daha iyi bir yaşam kalitesini beraberinde getirecektir.

Anahtar Kelimeler: Serebral Palsi, büyüme, diyet, malnutrisyon

Türkçe Kısa Başlık: Serebral Palsili Çocuklarda Beslenme 


\section{Determination of Nutritional Status in Children with Cerebral Palsy}

Melda Kangalgil ${ }^{1}$, Ayşe Özfer Özçelik ${ }^{2}$

${ }^{1}$ Department Of Health Science Faculty, Karadeniz Technical University, Trabzon, Turkey

${ }^{2}$ Department Of Health Science Faculty, Ankara University, Ankara, Turkey

\section{ABSTRACT}

INTRODUCTION: This study was planned and conducted to determine the nutritional status of children with Cerebral Palsy (CP), and the factors affecting it.

METHODS: The sample of the study consists of randomly selected 40 children diagnosed with CP, who were between the ages 7-17, who lived in the province of Ankara, and who were able to eat orally. Research data was collected by face to face interviews with one of the parents by a questionnaire. To determine the status of food consumption, one-day consumption information was obtained by the repeated 24-hour recalls.

RESULTS: Of the children, $60.0 \%$ were boys and $40.0 \%$ were girls with the mean age of $12.3 \pm 3.3$ years. It was determined that $30.0 \%$ of the children were extremely underweight, $20.0 \%$ were underweight, $12.5 \%$ were overweight, and $2.5 \%$ were obese while only $35.0 \%$ of them were found to have normal Body Mass Index (BMI). 52.5\% of the children had eating problems. Most common problems encountered during eating were keeping the food in the mouth $(73.5 \%)$, spilling the food over (58.0\%), and coughing or choking spells during eating (42.0\%). Of the most commonly encountered problems, drooling was most frequent (42.5\%). Of the reported problems encountered in less than two weeks, loss of appetite and constipation rank the second by $22.5 \%$; swallowing and chewing difficulties, and lack of interest in food rank third by $20.0 \%$. It was demonstrated that of the children with cerebral palsy, $80.0 \%$ had insufficient intake of fiber, $72.5 \%$ had insufficient intake of calcium, and $67.5 \%$ had insufficient intake of folate. In general, the energy intake was found not sufficient; while protein intake was adequate.

DISCUSSION AND CONCLUSION: To determine the feeding problems and improving the nutritional status by developing problem specific solutions will bring along better life quality for the children with $\mathrm{CP}$.

Keywords: Cerebral Palsy, growth, diet, malnutrition

İngilizce Kısa Başlık: Nutrition of Cerebral Palsy Children 


\section{Giriş}

Serebral Palsi (SP), gelişimini sürdürmekte olan beyin dokusunda oluşan hasar nedeniyle ortaya çikan kalıcı hareket ve postür bozukluğu ile karakterize, istemli motor aktivitelerde ve duyusal fonksiyonlardaki yetersizliktir. SP insidansı pek çok toplumda ortalama olarak 1000 canlı doğumda 23 olarak bildirilmiştir (1). Türkiye'de yapılan kapsamlı bir çalışmaya göre bu oran 1000 canlı doğumda 4,4 olarak belirlenmiştir (2).

Serebral Palsi'de beyin hasarının oluştuğu yere ve hasarın genişliğine bağlı olarak mental retardasyon, beslenme problemleri, işitme azlığı, dil ve konuşma bozuklukları, göz problemleri, davranış bozuklukları, uyku problemleri, ortopedik sorunlar ve üriner sistem bozuklukları gibi problemler görülmektedir $(1,3,4)$. SP'li çocuklarda beslenme problemleri bebeklikten başlayıp ömür boyu devam edebilen bir sorundur (3). SP'li çocuklarda beslenme problemlerinin görülme sıklı̆̆ının \%30,0-90,0 arasındayken malnutrisyon oranı \%90,0'lara ulaştığı bildirilmektedir (5). Serebral Palsili çocuklarda emme, çiğneme ve yutma güçlüğü, iştahsızlık, yeni besinlerin reddi, yemelerinin uzun sürmesi gibi nedenler ile fiziksel büyümeyi etkileyen beslenme problemleri görülebilir $(1,6,7)$. Bu beslenme problemleri tedavi edilmezse morbidite ve mortaliteyi olumsuz etkileyen büyüme ve gelişme geriliğine neden olabilmektedir (5). Kuzey Amerikan Pediatrik Gastroenteroloji, Hepatoloji ve Beslenme Komitesi (NASPGHAN) büyüme yetersizliği olan nörolojik engelli çocuklar için 2006 yılında yayınladığı raporda uygun beslenme desteğinin lineer büyüme, yaşam ve sağlık kalitesini arttırdığını kabul etmiştir (8).

Bu çalışma Serebral Palsili çocukların beslenme durumunu ve bunu etkileyen etmenleri belirlemek amacıyla planlanmış ve yürütülmüştür.

\section{Gereç ve Yöntem}

Araştırmanın örneklemini, Ankara ilinde yaşayan gelişigüzel örnekleme ile seçilen Serebral Palsi tanısı almış, 7-17 yaş aralığında olan ve oral beslenebilen 24 erkek ve 16 kız toplam 40 çocuk oluşturmuştur. Araştırma verileri anket formu ile çocukların ebeveynlerinden biri ile yüz yüze görüşülerek toplanmıştır. $\mathrm{Bu}$ çalışmada Helsinki deklarasyonu prensiplerine bağlı kalınmıştır. Ankete başlamadan önce 
çocukların velilerinden imzalı onamları alınmıştır. Antropometrik ölçüm olarak çocukların boy uzunluğu ve vücut ağırlığı ölçülmüştür. Boy uzunluğu ölçümü için standart bir mezura kullanılmıştır. Çocuğun fiziksel durumuna göre ayakta ya da yatar pozisyonda baş ve ayak tabanı arasındaki mesafe duvara veya mat üzerine işaretlenerek aradaki mesafe ölçülüp sonuçlar santimetre cinsinden kaydedilmiştir. Vücut ağırllğı ölçümleri baskülle çocuğun fiziksel durumuna göre anne kucağında (anne ile birlikte tartılan çocuğun ağırlığı anne ağırlığından çıkarılarak hesaplanmıştır) ya da bağımsız olarak ayakta ölçüm yapılmıştır. Boy uzunluğu ve vücut ağırlıkları kullanılarak çocukların beden kütle indeksleri hesaplanmıştır. Yaşa göre beden kütle indeksi persentil değerleri WHO'nun referans değerlerine göre $<5$. persentil "çok zayıf", $\geq 5$.- $<15$. persentil "zaylf", $\geq 15$.- $\leq 85$. persentil "normal", $\geq 85$. $<95$. persentil "hafif şişman" ve $\geq 95$. persentil “obez" olarak sınıflandırılmıştır (9). Serebral Palsi sınıflandırılmasında İsveç kriterleri (motor bozukluğuna göre; spastik, diskinetik ve ataksik; ekstrem tutulumuna göre kuadriplejik, diplejik ve hemiplejik) baz alınmıştır (10).

Çocukların besin tüketim durumunu belirlemek için 24 saatlik geriye dönük hatırlatma yöntemi ile bir günlük besin tüketimleri öğrenilmiştir. Besinlerin miktarlarının belirlenmesinde Yemek ve Besin Fotoğraf Kataloğu: Ölçü ve Miktarlar kitabından yararlanılmış, tüketilen besinlerin tür ve miktarları belirlenmiştir (11). Çocukların ev dışında tükettikleri yemekler değerlendirilirken standart tarifelerinden yararlanılmıştır $(12,13)$. Günlük tüketilen besinlerin enerji, makro ve mikro besin ögeleri değerleri Beslenme Bilgi Sistemleri (BeBİS) programı kullanılarak hesaplanmıştır. Günlük ortalama olarak alınan enerji ve besin ögeleri, yaş grubu ve cinsiyet için günlük alınması önerilen miktarlarla (Dietary Referance Intake) karşılaştırılarak, alım yüzdeleri (\%) hesaplanmıştır (14). Enerji ve besin ögeleri değerlendirmesi gereksinime göre \%67-133 olanlar yeterli, <\%67 olanlar yetersiz, >\%133 olanlar ise gereksinime göre fazla olarak kabul edilmiştir (15). Araştırma sonucunda elde edilen veriler SPSS istatistik programı ile değerlendirilmiş, mutlak ve yüzde (\%) değerleri ile tablolarda gösterilmiştir.

\section{Bulgular}

Çalışmaya daha önceden SP tanısı konmuş, 7-17 yaşları arasında 40 Serebral Palsili çocuk dahil edilmiştir. Çocukların genel özellikleri Tablo 1'de verilmiştir. 
Tablo 1: Çocukların Genel Özellikleri

\begin{tabular}{lrc}
\hline Çocukların genel özellikleri & N & \% \\
\hline Cinsiyet & 24 & 60,0 \\
Erkek & 16 & 40,0 \\
Kız & & \\
Doğum ağırlı̆̆ı (g) & 14 & 35,0 \\
Düşük doğum ağılı̆ı̆ı (<2500 g) & 26 & 65,0 \\
Normal doğum ağırlığı $(2500-4000$ g) & & \\
Prematüre sınıflandırması & 9 & 22,5 \\
Illeri derece preterm (24-31 hafta) & 20 & 50,0 \\
Orta derece preterm (32-36 hafta) & 1 & 2,5 \\
Sınırda preterm (37 hafta) & 10 & 25,0 \\
Normal (>37 hafta) & & \\
Doğum şekli & 19 & 47,5 \\
Vajinal doğum & 20 & 50,0 \\
Sezaryen & 1 & 2,5 \\
Vakum & & \\
Anne sütü alma durumu & 34 & 85,0 \\
Aldı & 6 & 15,0 \\
Almadı & & \\
Ekstremite tutulumuna göre sınıflandırma & 17 & 42,5 \\
Kuadriplejik & 16 & 40,0 \\
Diplejik & 7 & 17,5 \\
Hemiplejik & & \\
Kronik hastalık & 21 & 52,5 \\
Var & 19 & 47,5 \\
\hline Yok & $\mathbf{4 0}$ & $\mathbf{1 0 0 , 0}$ \\
\hline Toplam & &
\end{tabular}

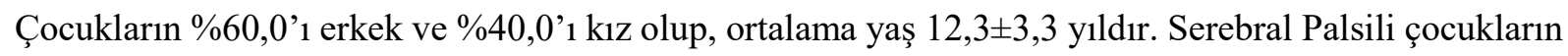
\%75,0'i erken doğmuş, \%35,0'i düşük doğum ağılıklı olup, \%50,0'si sezaryen ile doğmuştur. Çocukların Serebral Palsi teşhisi aldıkları ortalama yaş $8,96 \pm 7,48$ ay olarak saptanmıştır. Serebral Palsili çocuklar motor bozukluğuna göre sınıflandırıldığı zaman, tamamının spastik olduğu belirlenmiştir. Ekstremite tutulumuna göre sinıflandırıldığında ise \%42,5'i kuadriplejik, \%40,0'1 diplejik ve \%17,5'i hemiplejiktir. Ebeveynlerin beyanlarına göre çocukların \%52,5'inin kronik hastalıkları olup büyük bir çoğunluğunda $(\% 85,5)$ epilepsi vardır. Çocukların büyük çoğunluğu $(\% 85,0)$ anne sütü almıştır. İlk 6 ay sadece anne sütü verilenlerin oranı ise $\% 42,5$ 'tur.

Şekil 1: Çocukların yaşa göre BKİ persentil değerlendirmesi

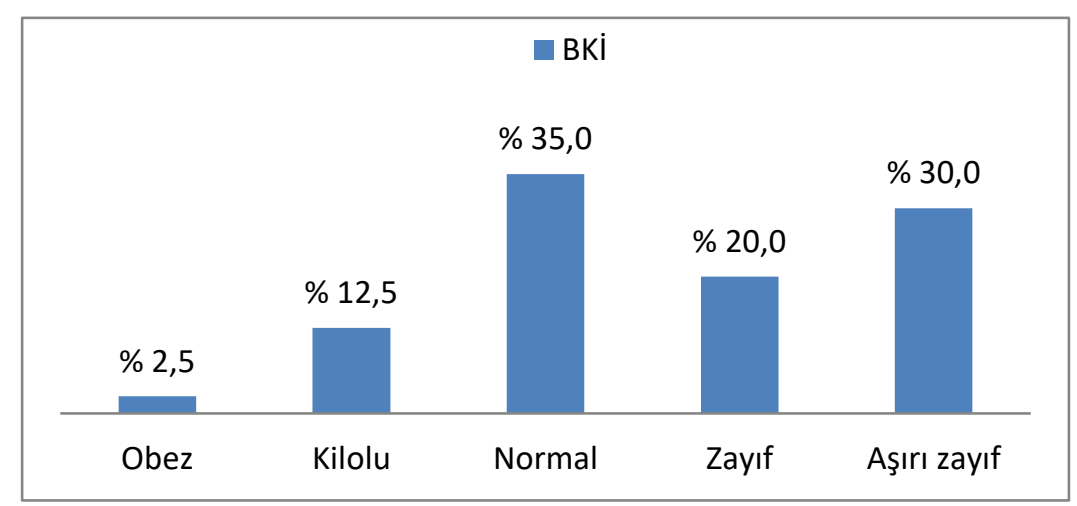


Çocukların vücut ağıllıkları ve boy uzunluğu ölçümlerine kullanılarak hesaplanan Beden Kütle İndeksi (BKI) persentillerinin yaşa göre değerlendirilmesi Şekil 1'de verilmiştir. Çocukların \%30,0'unun aşırı zayıf, \%20,0'sinin zayıf, \%12,5'inin kilolu ve \%2,5'inin obez olduğu bulunurken; sadece \%35,0'inin normal vücut ağırlığında olduğu saptanmıştır.

Tablo 2: Çocukların Beslenme Özellikleri

\begin{tabular}{|c|c|c|}
\hline Çocukların beslenme özellikleri & $\mathbf{N}$ & $\%$ \\
\hline \multicolumn{3}{|l|}{ Beslenme ürünü } \\
\hline Kullanmiyor & 29 & 72,5 \\
\hline Kullaniyor & 11 & 27,5 \\
\hline \multicolumn{3}{|c|}{ Bir öğünde yaklaşık beslenme süresi (dk) } \\
\hline $0-30$ & 33 & 82,5 \\
\hline $31-60$ & 6 & 15,0 \\
\hline $61-121$ & 1 & 2,5 \\
\hline \multicolumn{3}{|l|}{ Yemek yeme ile ilgili problem } \\
\hline Yok & 21 & 52,5 \\
\hline Var & 19 & 47,5 \\
\hline \multicolumn{3}{|l|}{ Reddedilen besin } \\
\hline Yok & 17 & 42,5 \\
\hline Var & 23 & 57,5 \\
\hline \multicolumn{3}{|c|}{ Bireyin beslenme problemlerinde diyette düzenleme } \\
\hline Yok & 31 & 77,5 \\
\hline Var & 9 & 22,5 \\
\hline \multicolumn{3}{|c|}{ Yemek yeme yönünden bağımlılık durumu } \\
\hline Bağımsız & 19 & 47,5 \\
\hline Az bağımlı & 16 & 40,0 \\
\hline Orta bağımlı & 4 & 10,0 \\
\hline Tam bağımlı & 1 & 2,5 \\
\hline \multicolumn{3}{|l|}{ Bireye özel yemek yapılma durumu } \\
\hline Yapilmaz & 28 & 70,0 \\
\hline Yapilır & 9 & 22,5 \\
\hline Bazen yap1lır & 3 & 7,5 \\
\hline \multicolumn{3}{|l|}{ Çocukların ana öğün sayısı } \\
\hline 2 ana öğün & 3 & 7,5 \\
\hline 3 ana öğün & 37 & 92,5 \\
\hline \multicolumn{3}{|l|}{ Çocuklar ara öğün } \\
\hline Tüketmez & 2 & 5,0 \\
\hline Tüketir & 38 & 95,0 \\
\hline \multicolumn{3}{|l|}{ Çocukların ara öğün sayısı (n=38) } \\
\hline 1 ara ögün & 16 & 42,1 \\
\hline 2 ara öğün & 20 & 52,6 \\
\hline 3 ara öğün & 2 & 5,3 \\
\hline
\end{tabular}

Araştırmaya katılan çocukların hepsi oral beslenebilmekte olup nazogastrik tüple ve gastrostomi tüpüyle beslenen çocuk yoktur. Tablo 2'de çocukların beslenmelerine ait bilgiler verilmiştir. Çocukların \%27,5'inin beslenme ürünü kullandığı, bunların da en çok enteral beslenme ürünlerini $(\% 72,6)$ kullandığı belirlenmiştir. Bir öğünde yaklaşık ne kadar zamanda yemek yedikleri sorgulandığında; 
çocukların \%82,5'inin 30 dakikadan daha az, \%15'inin 31-60 dakika ve \%2,5'inin 61-121 dakikada yemek yedikleri saptanmıştır. Çocukların \%52,5'inin yemek yeme ile ilgili problemleri olduğu, \%42,5'inin bazı besinleri reddettikleri belirlenmiştir. Yemek yerken en çok görülen problemler; yemeği ağızda bekletme $(\% 73,5)$, yemek sırasında yiyecekleri dökme $(\% 58,0)$ ve yemek sırasında öksürme veya tıkanma nöbetidir $(\% 42,0)$. En çok reddedilen besinler; süt $(\% 30,5)$, sebze $(\% 26,0)$, et ve et ürünleri $(\% 22,0)$ ve peynirdir $(\% 22,0)$. Çocukların sadece $\% 22,5$ 'inin diyetinde düzenlemeler yapıldı̆̆ı; en çok yapılan diyet düzenlemesi ise aynı gün içerisinde besin çeşitliliğini sağlamak olduğu belirlenmiştir (\%88,8). Araştırmaya katılan çocukların \%47,5'inin kendi kendine yemek yiyebildiği (bağımsız), \%40,0'ının çatal bıçağı kendi tutabilmesine rağmen yardımsız yemek yiyemediği (az bağımlı), \% 10,0'unun çatalını bıçağını yardımla tutabildiği (orta bağımlı), \%2,5' 'inin yardımsız yemek yiyemediği (tamamen bağımlı) saptanmıştır. Çocukların \%22,5'ine her zaman ve \%7,5'ine bazen özel yemek yapıldığı; \%58,3'ünün yemek kıvamının normal, \%33,4'ünün püre şeklinde, \%8,3’ünün sulu olduğu belirtilmiştir. Çocukların \%92,5'inin günde sabah, öğle, akşam olmak üzere 3 ana ögün ve \%7,5'inin sabah ve akşam olmak üzere 2 ana öğün yemek yedikleri; \%95,0'inin ara ögünlerde bir şeyler tükettikleri belirlenmiştir. Çocukların \%52,6'sının günlük ara öğün sayısının iki, \%5,3’ünün üç olduğu; en çok tüketilen ara ögünün $(\% 36,8)$ gece öğünü olduğu belirlenmiştir. Çocukların \%52,5'inin günde 4-5 bardak (800-1000 mL), \%20,0'sinin 2-3 bardak (400-600 mL) su tükettiği ifade edilmiştir.

Tablo 3: Beslenme ile ilişkili sorun görülme sıklığ1

\begin{tabular}{lcclc}
\hline Sorun & \multicolumn{2}{c}{ Sıklıkla $\geq \mathbf{2} / \mathbf{h a f t a}$} & \multicolumn{2}{c}{ Nadiren <2/hafta } \\
\cline { 2 - 5 } Yutma güçlü̆̆̈̈ & Sayı & Yüzde & Sayı & Yüzde \\
Konstipasyon & 9 & 20,0 & 32 & 80,0 \\
Kusma & 9 & 22,5 & 31 & 77,5 \\
Öğ̈̈rme & 2 & 5,0 & 38 & 95,0 \\
Öksürük & 8 & 20,0 & 32 & 80,0 \\
Tıkanma & 7 & 17,5 & 33 & 82,5 \\
Boğulma & 5 & 12,5 & 35 & 87,5 \\
Besinlere ilgisizlik & 3 & 7,5 & 37 & 92,5 \\
Salya akması & 8 & 20,0 & 32 & 80,0 \\
İştahsızlık & 17 & 42,5 & 23 & 57,5 \\
\hline
\end{tabular}

S1klıkla rastlandığı belirtilen sorunlarda en yüksek oranı salya akması almıştır $(\% 42,5)$. İki haftadan daha kısa süre içinde karşılaşıldığı belirtilen sorunlarda \%22,5 ile iştahsızlık ve konstipasyon ikinci, yutma ve çiğneme güçlüğü, besinlere ilgisizlik \%20,0 ile üçüncü sıradadır (Tablo 3). 
Yaş gruplarına göre enerji, makro ve mikrobesin alımının karşılanma durumu Tablo 4'de verilmiştir. 79 yaş aralığındaki Serebral Palsili çocukların \%88,9'unun posa, \%33,3'ünün demir, kalsiyum alımlarının yetersiz olduğu belirlenmiştir. 10-13 grubundaki çocukların özellikle enerji $(\% 61,5)$, posa $(\% 92,3)$, tiamin $(\% 53,8)$, folat $(\% 84,6)$, C vitamini $(\% 69,2)$, kalsiyum $(\% 92,3)$, fosfor $(\% 53,9)$, magnezyum $(\% 61,5)$ ve demir $(\% 53,8)$ alımlarının yetersiz olduğu görülmüştür. 14-17 yaş aralığındaki çocukların \%72,2'sinin günlük diyetle aldıkları enerji, magnezyum; \%77,8'inin tiamin, folat, kalsiyum; \%66,7'sinin posa alımlarının yetersiz olduğu görülürken; genel örneklemde Serebral Palsili çocukların \%80,0'inin posayı, \%72,5'inin kalsiyumu, \%67,5'inin folatı günlük diyetle yetersiz aldıkları belirlenmiştir.

Tablo 4: Yaş gruplarına göre enerji, makro ve mikrobesin, vitamin ve mineral alımının gereksinmeyi karşılama durumu

\begin{tabular}{|c|c|c|c|c|c|c|c|c|}
\hline \multirow{3}{*}{$\begin{array}{l}\text { Enerji veBesin } \\
\text { ögeleri }\end{array}$} & \multicolumn{8}{|c|}{$<\% 67$ DRI } \\
\hline & \multicolumn{2}{|c|}{ 7-9 yaş } & \multicolumn{2}{|c|}{ 10-13 yaş } & \multicolumn{2}{|c|}{ 14-17 yaş } & \multicolumn{2}{|c|}{ Toplam } \\
\hline & Sayı & $\%$ & Sayı & $\%$ & Sayı & $\%$ & Sayı & $\%$ \\
\hline Enerji (kkal) & 2 & 22,2 & 8 & 61,5 & 13 & 72,2 & 23 & 57,5 \\
\hline Protein (g) & - & - & 1 & 7,7 & 3 & 16,7 & 4 & 10,0 \\
\hline Posa $(g)$ & 8 & 88,9 & 12 & 92,3 & 12 & 66,7 & 32 & 80,0 \\
\hline A vitamini (mcg) & 1 & 11,1 & 2 & 15,4 & 3 & 16,7 & 6 & 15,0 \\
\hline E vitamini (mg) & - & - & 2 & 15,4 & 3 & 16,7 & 6 & 15,0 \\
\hline K vitamini (mcg) & - & - & - & - & - & - & - & - \\
\hline Tiamin (mg) & 2 & 22,2 & 7 & 53,8 & 14 & 77,8 & 23 & 57,5 \\
\hline Riboflavin (mg) & - & - & 2 & 15,4 & 4 & 22,2 & 6 & 15,0 \\
\hline Niasin (mg) & - & - & 2 & 15,4 & 4 & 22,2 & 6 & 15,0 \\
\hline $\mathbf{B}_{6}(\mathrm{mg})$ & - & - & 3 & 23,1 & 4 & 22,2 & 7 & 17,5 \\
\hline $\mathbf{B}_{12}(\mathrm{mcg})$ & - & - & 2 & 15,4 & 2 & 11,1 & 4 & 10,0 \\
\hline Folat (mcg) & 2 & 22,2 & 11 & 84,6 & 14 & 77,8 & 27 & 67,5 \\
\hline C vitamini (mg) & 2 & 22,2 & 9 & 69,2 & 5 & 27,8 & 16 & 40,0 \\
\hline Kalsiyum (mg) & 3 & 33,3 & 12 & 92,3 & 14 & 77,8 & 29 & 72,5 \\
\hline Fosfor (mg) & - & - & 7 & 53,9 & 8 & 44,4 & 15 & 37,5 \\
\hline Magnezyum (mg) & 1 & 11,1 & 8 & 61,5 & 13 & 72,2 & 22 & 55,0 \\
\hline Demir (mg) & 3 & 33,3 & 7 & 53,8 & 6 & 33,3 & 16 & 40,0 \\
\hline Çinko (mg) & - & - & 6 & 46,2 & 5 & 27,8 & 11 & 27,5 \\
\hline
\end{tabular}




\section{Tartışma}

$\mathrm{Bu}$ çalışma 7-17 yaş arası Serebral Palsili çocukların beslenme durumunu belirlemek amacıyla planlanmış ve yürütülmüştür. Beslenme bozukluğu ve büyüme geriliŭi SP de görülen önemli problemlerden biridir.

Serebral Palsi'nin nedeni çok çeşitli ve çok faktörlüdür. Prematüre doğum, düşük doğum ağırlığı ve zor doğum öyküsü risk faktörlerinden bazılarıdır $(1,16,17)$. Bu çalışmada SP’li çocukların, \%75,0'inin erken doğduğu ve \%35,0'inin düşük doğum ağırlıklı oldukları saptanmıştır (Tablo 1). Eriman ve ark.'nın (2009) yaptıkları çalışmada çocukların \%37,1'i düşük doğum ağırlıklı ve \%35,0'i prematüre doğum (18); Wang ve ark.'nın (2016) Çin'de 378 Serebral Palsili çocukla yaptıkları çalışmada çocukların \%43,8'i düşük doğum ağırlıklı ve \% 54,1'i prematüre doğum olduğu belirlenmiştir (19). Bu araştırmadaki çocukların yarısı $(\% 50,0)$ sezaryen ile doğmuştur. El ve ark. (2007) Türkiye'de yaptıkları çalışmada benzer olarak sezaryen doğum oranını \%45,0 olarak bulmuşlardır (20). Epilepsi SP’li çocuklarda önemli bir sorun olup, \%15,0-60,0 oranında görülmektedir (21). Kakooza-Mwesige ve ark. (2015) yaptıkları çalışmada çocukların \%45,2'sinde; Zelnik ve ark. (2010) \%33,0'ünde, Konuşkan ve ark. (2012) \%54,3’ünde; Karadağ Sayg1 ve ark. (2015) \%30,1'inde epilepsi olduğunu bildirmişlerdir (22-25). Bu araştırmada da diğer çalışmalara benzer olarak epilepsi sıklığ $\% 45,0$ olarak belirlenmiştir.

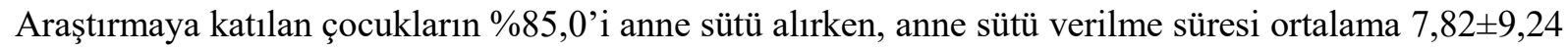
ay olarak belirlenmiştir. Nacitarhan (2005) Güneydoğu Anadolu'da yaşayan Serebral Palsili çocuklarla

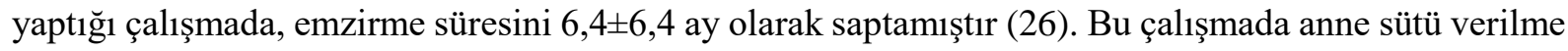
süresi normal aralıklarda bulunsa da ilk 6 ay sadece anne sütü verilme oranı $(\% 42,5)$ düşük olduğu tespit edilmiştir.

SP'li çocuklarda saptanan yemek yeme ile ilgili sorunlar, hastalığa ilişkin olumsuz özelliklerden kaynaklanmaktadır. Bansal ve ark.'nın (2014) 40 Serebral Palsili çocuk üzerinde yaptıkları çalışmada çocukların \%40,0'ının düşük kilolu, \%45,0'inin normal, \%7,5'inin hafif şişman ve \%7,5'inin obez olduğu saptanmıştır (27). Hurvitz ve ark. (2008) 137 Serebral Palsili çocukla yaptıkları çalışmada; \%18,2'sinin şişman, \%10,9'unun hafif şişman, \%29,1'inin ise ABD Hastalık Kontrol ve Korunma 
Merkezleri (CDC) kriterlerine göre normal ağırlıkta olduğu bulunmuştur (28). Wang ve ark.'nın (2016) Çin'de 378 Serebral Palsili çocuk üzerindeki yaptıkları çalışmada çocukların yaşa göre BKİ'leri değerlendirildiğinde \%59,9'unun normal ağırlıkta olduğu, \%21,5'inin zayıf, \%18,5'inin normalden daha fazla ağırlıkta olduğu ve tüm çocukların \%7,4'ünün obez olduğu görülmüştür (19). Bu çalışmadaki çocukların \%30,0'u aşırı zayıf, \%20,0'si zayıf, \%12,5'i hafif şişman ve \%2,5'i obez olarak bulunurken; sadece \%35,0’i normal BKİ persentili sınırlarındadır (Şekil 1). Düşük de olsa (\%2,5) SP’li çocuklarda görülen obezite hem iştahın iyi olmasından ve buna bağlı olarak yiyecek tüketiminin gereksinimin üzerinde olmasından; hem de hareketsizlikten kaynaklanabilmektedir. Bunun tam tersi aşırı zayıf olanlardaki $(\% 30,0)$ sorun da iştahsızlık, yutma güçlüğü ve dolayısıyla daha az besin tüketilmesi şeklinde açıklanabilir. Malnutrisyonun yanında obeziteyi de önlemek için enerji harcamasına dayalı bireyselleştirilmiş beslenme programı önerilmektedir (29). Serebral Palsili hastaların sorunlarının ve gereksinimlerinin doğru olarak saptanması ile bu çocukların fiziksel ve ruhsal yönden daha iyi duruma gelmeleri sağlanabilir (20).

Spastisite el ve kol hareketlerinde zorluğa neden olduğu için çocukların kendi kendine beslenmesini olumsuz etkilemektedir (3). Bu çalışmada çocukların \%47,5'inin bağımsız yemek yiyebildiği belirlenmiştir. Karagiozoglou-Lampoudi ve ark. (2012) çocukların sadece \%17,7’sinin; Şimşek ve ark. (2014) ise \%34,2'sinin kendi kendine yemek yiyebildiklerini saptamışlardır (30, 31). Ayrıca çocukların \%49,6'sının bir öğündeki beslenme süresi 30 dakikadan az iken, \%41,7'sinin 31-60 dk, \%5,8'inin 61120 dk ve \%2,9'unun 121 dakikadan uzun sürdüğü bulunmuştur. Araştırmaya katılan çocukların büyük çoğunluğunun $(\% 82,5)$ yemek yeme süresinin 30 dakikadan daha az, \%15'inin 31-60 dk, \%5,8'inin 61$121 \mathrm{dk}$ olduğu tespit edilmiştir. Erkin ve ark. (2010) yaptıkları çalışmada çocukların \%7,5'inin oral enteral beslenme desteği kullandıklarını belirtmişlerdir (32). Bu çalışmada ise bu oran daha yüksek $(\% 20,0)$ bulunmuştur. Çocukların \%52,5'inin yemek yeme ile ilgili problemleri olduğu, \%42,5'inin bazı besinleri reddettikleri belirlenmiştir. Yemek yerken en çok görülen problemler; yemeği ağzında bekletme $(\% 73,5)$, yemek sırasında yiyecekleri dökme $(\% 58,0)$ ve yemek sırasında öksürme veya tıkanma nöbetidir $(\% 42,0)$. Yeterli ve dengeli beslenebilmek için günde en az 3 öğün beslenme önerilmektedir (33). Çocukların \%92,5'inin günde 3 ana öğün yemek yediği belirlenmiştir (Tablo 2). 
Ögün sayısı ile öğünlere düşen enerji ve besin ögelerinin miktarı vücudun fizyolojik dengesini sağlamada önemli rol oynamaktadır.

Gastrointestinal sorunlar SP'li çocuklarda \%80,0-90,0 oranında görülmektedir (34). Konstipasyon SP'li çocuklarda yaygın olarak görülen komplikasyonlardandır. Bunun da bu bireylerde hareket yetersizliğinden ve posalı besinlerin tüketimindeki zorluklardan kaynaklanabileceği ileri sürülmektedir. Araştırma kapsamındaki çocukların \%22,5'inin sıklıkla konstipasyon problemi olduğu bulunmuştur. Erkin ve ark.'nın (2010) 120 SP'li çocukla yaptığı çalışmada çocukların \%21,7'sinde disfonksiyon, \%25,0'inde konstipasyon, \%19,2'sinde çiğneme problemi vardır (32). Oral motor ve çiğneme yutma fonksiyon bozuklukları yemeğe uzun zaman harcanmasına ve yemek sırasında ağızdan yiyeceklerin dökülmesine neden olarak yetersiz besin alımına sebep olmaktadır $(5,33)$. Bu çalışmaya katılanların \%20,0'sinde de benzer olarak yutma ve çiğneme güçlüğü olduğu belirlenmiştir (Tablo 3). Araştırmaya katılan çocukların günlük diyetleri ile aldıkları enerji ve protein alımları değerlendirildiği zaman, $\% 57,5^{\prime}$ inin enerji alımının yetersiz, \%67,5'inin protein alımının yeterli olduğu belirlenmiştir. Calis ve ark. (2010) da yaptıkları çalışmada çocukların önerilenden düşük enerji alırken, önerilenden fazla protein aldıklarını bulmuşlardır (29).

Diyet besin ögelerinden yetersiz olduğu zaman vücuttaki depolar tükenmeye başlar. Tiamin, $\mathrm{B}_{6}$ ve C gibi suda eriyen vitaminlerin deposu oldukça sınırlıdır ve birkaç hafta içinde eksiklikleri oluşabilir (8). Hillesund ve ark. (2007) 4 günlük besin tüketimini değerlendirdikleri SP’li çocukların vitamin E alımlarının düşük olduğunu saptamışlardır (7). Grammatikopoulou ve ark. (2009) benzer şekilde vitamin E alımının SP'li çocuklarda düşük olduğunu bulmuşlardır (35). Çalışmaların aksine bu araştırmada genel olarak E vitaminin alımının yeterli olduğu belirlenmiştir. Araştırmaya katılan çocukların yaklaşık 1/3'ünün tiamin $(\% 35,0)$, niasin $(\% 35,0)$ folik asit $(\% 32,5)$ alımlarının yetersiz olduğu saptanmıştır. Sullivan ve ark. (2002) SP’li 100 çocuğu değerlendirdikleri bir çalışmada tiamin ve riboflavin alımının yetersiz olduğunu ve çocukların kendi kendine beslenemediğini bildirmişlerdir (36). Hillesund ve ark.'nın (2007) yaptıkları çalışmada SP'li çocukların \%71,0'inin multivitamin takviyesi aldığı buna rağmen folik asit alımının yetersiz olduğu saptanmıştır (7). Bu çalışmadaki çocukların A vitamin $(\% 52,5), \mathrm{K}$ vitamini $(\% 95)$, riboflavin $(\% 47,5), \mathrm{B}_{12}(\% 80)$ vitaminleri alımı gereksinimlerine göre 
yeterli, bazı gruplarda gereksinime göre fazla bulunmuştur (Tablo 4). Ancak SP'li çocuklarda A vitamininin yetersiz olduğunu gösteren çalışmalar da vardır (35-37). Araştırmada yaşa göre önerilen günlük mineral gereksinimi karşılama durumuna bakıldığı zaman demir alımının çocukların \%40,0'1nda yetersiz olduğu bulunmuştur (Tablo 4). Sullivan ve ark. (2002) yaptıkları çalışmada diyetle demir alımının katılımcıların yaklaşık yarısında normal sınırın altında olduğuna dikkat çekmişlerdir (36). Yetersiz demir alımı çocukların tükettiği tüm besinler içinde süt ve süt bazlı içeceklerin enerji sağlama açısından en yüksek paya sahip olması ve sütün demirin zayıf kaynağı olması ile açıklanmıştır. Loisa ve ark. (2009) da demir alımını önerilen değere göre \%87,0 oranında düşük olduğunu bulmuşlardır (37). Araştırmaya katılan çocukların \%72,5'inin yetersiz kalsiyum aldığı saptanmıştır (Tablo 4). Grammatikopoulou ve ark. (2009) SP’li ve sağlıklı çocukların tüketimini araştırdıkları çalışmada kalsiyum alımının her iki grupta da yeterli olduğunu bulmuşlardır (35). Loisa ve ark. (2009) SP'li çocukların \%19,0'unda önerilen değerin altında kalsiyum alımı olduğunu tespit etmişlerdir (37). Kalsiyum alımının düşük olduğunu saptayan başka çalışmalar da vardır $(7,38)$. Çalışmada magnezyum, fosfor ve çinko alımı değerlendirilmiş, çocukların \%42,5'inin magnezyum, \%42,5'inin fosfor, \%57,5'inin çinko alımlarının yeterli düzeyde olduğu görülmüştür (Tablo 4). Loisa ve ark.'nın (2009) 54 SP'li çocukla yaptıkları çalışmada fosfor alımının önerilenin 2 katından fazla olduğu bulunmuştur (37). Schoendorfer ve ark. (2010) gastrointestinal disfonksiyon nedeniyle emilimin bozulması, antikonvülsan, diüretik veya kortikosteroid kullanımının vitamin mineral gereksinimini değiştirebileceğini belirtmişlerdir (8).

Sonuç: Yutma güçlügü, salya akması, beslenme sırasında öğürme ve öksürme, iştahsızlık, konstipasyon gibi gastrointestinal sistem problemleri, beslenme yönünden bağımlılık, SP'li çocuklarda beslenme yetersizliklerine neden olmaktadır. Bu beslenme yetersizlikleri nedeniyle SP'li çocuklarda malnutrisyon erken dönemde başlayarak zaman içerisinde ilerleme gösterebilmektedir. Beslenme sorunlarının saptanması ve soruna özel çözümün belirlenmesi ile beslenme durumunun geliştirilmesi, daha az komplikasyon ve SP'li çocuklar için daha iyi bir yaşam kalitesi beraberinde getirecektir. Serebral Palsili çocuklar beslenme yetersizliği açısından risk altında olduğundan besin tüketimleri takip edilmeli, doktor, diyetisyen, fizyoterapist işbirliğiyle aileye ve çocuğa gereken bilgi ve eğitim verilmelidir. 


\section{Kaynaklar}

1. Sankar C, Mundkur N. Cerebral palsy- definition, classification, etiology and early diagnosis. Indian J Pediatr 2005;72:865-8.

2. Serdaroğlu A, Cansu A, Özkan S, Tezcan S. Prevalence of Cerebral Palsy in Turkish children between the ages of 2 and 16 years. Dev Med Child Neurol 2006;48:413-6.

3. Clawson EP, Kuchinski KS, Bach R. Use of behavioral interventions and parent education to address feeding difficulties in young children with spastic diplegic Cerebral Palsy. Neuro Rehabilitation 2007;22:397-406

4. Reid SM, Modak MB, Berkowitz RG, Reddihough DS. A population-based study and systematic review of hearing loss in children with Cerebral Palsy. Dev Med Child Neurol 2011;53:1038-45.

5. Vargün R, Ulu HÖ, Duman R, Yağmurlu A. Serebral Palsili çocuklarda beslenme problemleri ve tedavisi. Ankara Üniversitesi Tıp Fakültesi Mecmuası 2004;57:257-65.

6. Özsaras N. Serebral Palsi ile Yaşamak: Aileler ve Hastalar İçin Bilgiler. Pediatrik Ortopedi ve Rehabilitasyon Dizisi 4. Kitap. İstanbul;2002.

7. Hillesund E, Skranes J, Trygg KU, Bohmer T. Micronutrient status in children with Cerebral Palsy. Acta Pædiatrica 2007;96:1195-8.

8. Schoendorfer N, Boyd R, Davies PSW. Micronutrient adequacy and morbidity: paucity of information in children with Cerebral Palsy. Nutrition Reviews 2010;68:739-48.

9. WHO Multicentre Growth Reference Study Group. WHO Child Growth Standards: Length/height-for-age, weight-for-age, weight-for-length, weight-for-height and body mass index-for-age: Methods and development. Geneva: World Health Organization, 2006.

10. Mutch L, Alberman E, Hagberg B, Kodama K, Perat MV. Cerebral Palsy epidemiology: where are we now and where are we going? Dev Med Child Neurol 1992;34:547-51.

11. Rakıcıŏglu N, Tek NA, Ayaz A. Yemek Ve Besin Fotoğraf Kataloğu: Ölçü Ve Miktarlar. 3. Bask1, Ankara: Hatipoğlu Yayınevi; 2012. s.11-131

12. Baysal A. Yemek planlama. Beslenme. 13. Bask1, Ankara: Hatipoğlu Yayınevi; 2011. s.430-8. 
13. Kutluay Merdol T. Standart Yemek Tarifeleri. 4. Bask1, Ankara: Hatipoğlu Yayınevi;2011. s. $31-124$

14. Otten JJ, Hellwig JP, Meyers LD, (eds). Dietary Reference Intakes Applications in Dietary Assessment. Washington DC: National Academy Press;2000.

15. NAP. Nutrient Adequacy-Assessment Using Food Consumption Surveys. Washington DC: National Academy Press;1986. p.14.

16. Özaras N, Yalçın S, (eds). Serebral Palsi Tedavi ve Rehabilitasyon. İstanbul; 2000.

17. Bialik GM, Givon U. Cerebral palsy: classification and etiology. Acta Orthopaedica et Traumatologica Turcica 2009;43:77-80.

18. Eriman EÖ, İçağasığlu A, Demirhan E, Kolukısa, Ş, Aras H, Haliloğlu S, ve ark. Serebral Palsili 202 olgunun demografik verileri ve klinik özellikler. The Turkish Journal of Physical Medicine and Rehabilitation 2009;55:94-7.

19. Wang F, Cai Q, Shi W, Jiang H, Li N, Ma D, et al. A cross-sectional survey of growth and nutritional status in children with Cerebral Palsy in West China. Pediatric Neurology 2016;58:90-7.

20. El Ö, Peker Ö, Bozan Ö, Berk H, Koşay C. Serebral Palsi hastalarının genel özellikleri. DEÜ tıp fakültesi dergisi 2007;21:75-80.

21. Kulak W, Sobaniec W. Risk factors and prognosis of epilepsy in children with Cerebral Palsy in north-eastern Poland. Brain Dev 2003;25:499-506.

22. Kakooza-Mwesige A, Forssberg H, Eliasson AC, Tumwine JK. Cerebral Palsy in children in Kampala, Uganda: clinical subtypes, motor function and co-morbidities. BMC research notes $2015 ; 8: 166$.

23. Zelnik N, Kompnicki M, Bennett-back O, Castel-deutsch T, Tirosh E. Risk factors for epilepsy in children with Cerebral Palsy. Eur J PAediatr Neurol 2010;14:67-72.

24. Konuşkan B, Per H, Gümüş H, Kumandaş S. Serebral Palsili olgularda görme ve işitme bozuklukları ve epilepsi sıklı̆ğ. Journal of Clinical and Experimental Investigations 2012;3:245-9. 
25. Karadağ Saygı E, Giray E, Cerşit HP, Ulutatar F, Aydın R. Serebral Palsili çocuğu olan ailelerin aile ortamlarının değerlendirilmesi ve gereksinimlerinin belirlenmesi. Turk J Phys Med Rehab $2015 ; 61: 320-5$.

26. Nacitarhan S. Merkezimize başvuran güneydoğu anadolu bölgeli Serebral Palsili çocukların sosyoekonomik ve demografik özellikleri. Dicle Tıp Dergisi 2005;32:13-9.

27. Bansal A, Diwan S, Diwan J, Vyas N. Prevalance of obesity in children with Cerebral Palsy. Journal of Clinical and Diagnostic Research 2014;8:08-11.

28. Hurvitz EA, Green LB, Hornyak JE, Khurana SR, Koch LG. Body mass index measures in children with Cerebral Palsy related to gross motor function classification: a clinic-based study. American Journal of Physical Medicine \& Rehabilitation 2008;87:395-403.

29. Calis EA, Veugelers R, Rieken R, Tibboel D, Evenhuis HM, Penning C. Energy intake does not correlate with nutritional state in children with severe generalized Cerebral Palsy and intellectual disability. Clinical Nutrition 2010;29:617-21.

30. Karagiozoglou-Lampoudi T, Daskalou E, Vargıami E, Zafeiriou D. Identification of feeding risk factors for impaired nutrition status in paediatric patients with Cerebral Palsy. Acta Paediatrica 2012;101:649-54.

31. Şimşek TT, Tuç G. Serebral Palsili çocuklarda beslenme problemleri ve büyüme üzerine etkisi. Journal of Current Pediatrics/Guncel Pediatri 2014;12:73-80.

32. Erkin G, Culha C, Ozel S, Kırbıyık EG. Feeding and gastrointestinal problems in children with Cerebral Palsy. International Journal of Rehabilitation Research 2010;33:218-24.

33. T.C. Sağlık Bakanlığı Temel Sağlık Hizmetleri Genel Müdürlüğü. Türkiye’ye özgü beslenme rehberi. Ankara;2006.

34. Chong SK. Gastrointestinal problems in the handicapped child. Curr Opin Pediatr 2001;13:4416.

35. Grammatikopoulou MG, Daskalou E, Tsigga M. Diet, feding practices, and anthropometry of children and adolescents with Cerebral Palsy and their siblings. Nutrition 2009;25:620-6. 
36. Sullivan PB, Juszczak E, Lambert BR, Rose M, Ford-Adams ME, Johnson A. Impact of feeding problems on nutritional intake and growth: Oxford Feeding Study II. Developmental Medicine \& Child Neurology 2002;44:461-7.

37. Loisa PK, Pihko H, Vesander U, Paganus A, Ritanen U, Makitie O. Insufficient energy and nutrient intake in children with motor disability. Acta Pædiatrica 2009;98:1329-33.

38. Erkin G, Kaçar S, Özel S. Serebral Palsili hastalarda gastrointestinal sistem ve beslenme problemleri. Türkiye Fiziksel T1p ve Rehabilitasyon Dergisi 2005;51:150-5. 